\title{
FAKTOR-FAKTOR YANG BERHUBUNGAN DENGAN KUNJUNGAN PEMERIKSAAN IVA DI KELURAHAN PATIH GALUNG KOTA PRABUMULIH TAHUN 2020
}

\author{
FACTORS RELATED TO THE IVA EXAMINATION VISIT IN PATIH GALUNG VILLAGE \\ PRABUMULIH CITY IN 2020
}

\author{
Pera Mandasari \\ Aksdemi Kebidanan Rangga Husada Prabumulih, Sumatera Selatan \\ email:dwipera86@yahoo.com
}

\begin{abstract}
ABSTRAK
Deteksi dini kanker servik dengan metode Inspeksi Visual Asam Asetat(IVA) merupakan skrining alternatif selain Papsmear. Tujuan penelitian adalah untuk mengetahui Faktor-Faktor yang Berhubungan dengan Kunjungan Pemeriksaan IVA di Kelurahan Patih Galung Kota Prabumulih Tahun 2020. Metode penelitian bersifat analitik, dengan mengunakan pendekatan Cross Sectional. Populasi penelitian ini adalah semua ibu-ibu yang berada di kelurahan Patih Galung yang hadir dalam kunjungan pemeriksaan IVA. Sampel penelitian adalah ibu-ibu yang sudah menikah yang datang berkunjung ke pemeriksaan IVA yaitu 45 orang. Instrumen penelitian berupa kuesioner. Hasil penelitian berdasarkan analisa univariat diketahui bahwa dari 45 responden terdapat 32 responden $(71,1 \%)$ yang pernah melakukan kunjungan pemeriksaan IVA dan 13 responden (28,9\%) yang tidak pernah melakukan kunjungan pemeriksaan IVA, terdapat 35 orang $(77,8 \%)$ yang memiliki usia resiko rendah dan 10 orang $(22,2 \%)$ yang memiliki usia resiko tinggi, terdapat 36 responden (80\%) yang memiliki pengetahuan baik dan 9 responden (20\%) yang memiliki pengetahuan kurang, terdapat 33 orang $(73,3 \%)$ memiliki pendidikan tinggi dan 12 orang $(26,7 \%)$ yang memiliki pendidikan rendah. Dari analisa bivariat diketahui bahwa dari 35 responden yang memilliki usia resiko rendah terdapat 29 responden $(64,4 \%)$ yang pernah melakukan kunjungan pemeriksaan IVA sedangkan dari 10 responden yang memiliki usia resiko tinggi terdapat 3 responden $(6,7 \%)$ yang pernah melakukan kunjungan pemeriksaan IVA. Kesimpulan ada hubungan yang bermakna antara umur ibu dengan kunjungan pemeriksaan IVA dengan nilai Pvalue 0,003< $\alpha 0,05$, ada hubungan yang bermakna antara pengetahuan dengan kunjungan pemeriksaan IVA dengan nilai Pvalue $0,001<$ 0,05 dan ada hubungan yang bermakna antara pendidikan ibu dengan kunjungan pemeriksaan IVA dengan nilai Pvalue $0,000<0,05$.
\end{abstract}

Kata Kunci : Kunjungan Pemeriksaan IVA, Pengetahuan Ibu, Pendidikan Ibu

\begin{abstract}
Cervical Cancer is a malignancy in the cervix or uterine cervix. Early detection of cervical cancer with the Visual Inspection Method of Acetic Acid (IVA) is an alternative screening besides Pap smear.

The purpose of this study was to determine the Factors Associated with the Patih Galung Village Iva Inspection Visit in 2020. The research method was analytic, using a cross sectional approach. The study population was all mothers in the District of Patih Galung who attended the IVA examination visit. The sample of the study were 45 married mothers who came to visit the IVA examination. The research instrument was in the form of a questionnaire. The results of the study based on univariate analysis revealed that out of 45 respondents there were 32 respondents (71.1\%) who had visited an IVA examination and 13 respondents (28.9\%) who had never visited an IVA examination, there were 35 people (77.8\%) ) who have a low risk age and 10 people (22.2\%) who have a high risk age, there are 36 respondents (80\%) who have good knowledge and 9 respondents (20\%) who have less knowledge, there are 33 people (73, 3\%) have higher education and 12 people (26.7\%) have low education. From the bivariate analysis it is known that of the 35 respondents who had a low risk age there were 29 respondents $(64.4 \%)$ who had visited an IVA examination while out of 10 respondents who had a high risk age there were 3 respondents (6.7\%) who had visited IVA examination. Conclusion there is a significant relationship between maternal age with IVA examination visit with a p-value of $0.003<\alpha 0.05$, there is a significant relationship between knowledge with IVA examination with a p-value of $0.001<0.05$ and there is a significant relationship between education of mothers with IVA examination visits with a p-value of 0,000 $<0.05$.
\end{abstract}

Keywords: IVA examination visits, mother's knowledge, mother's education 
CENDEKIA MEDIKA

p-ISSN: 2503-1392

e-ISSN: 2620-5424

\section{PENDAHULUAN}

Kanker serviks merupakan suatu penyakit keganasan pada leher rahim atau serviks uteri. Kanker ini menempati urutan keempat dari seluruh keganasan pada wanita di dunia setelah kanker payudara, kolorektum dan paru. Insiden kanker serviks sekitar $7,9 \%$ di dunia (IARC, 2014). Sampai saat ini, kanker serviks masih menjadi masalah kesehatan perempuan di negara-negara berkembang termasuk di Indonesia sehubungan dengan angka kejadian dan angka kematiannya yang tinggi ${ }^{1}$

Dari penelitian Sapto Wiyono (2008) dapat diketahui bahwa faktor resiko yang mempengaruhi terjadinya kanker serviks adalah perempuan yang melakukan pernikahan dini, hal tersebut disebabkan karena pada usia tersebut terjadi perubahan lokasi sambungan skuamokolumner sehingga relatif lebih peka terhadap stimulasi onkogen. Selain itu dalam penelitian yang dilakukan oleh Sapto Wiyono (2008), ada faktor lain penyebab kanker serviks yaitu jumlah paritas lebih dari 3 mengakibatkan frekuensi kanker serviks menjadi 3 kali dan pekerja seksual merupakan kelompok resiko tinggi oleh karena tingginya kemungkinan infeksi HPV. Studi epidemiologik menunjukan 90-95\% kanker serviks berkaitan dengan infeksi HPV yang ditularkan melalui hubungan seksual..

\section{Menurut WHO (World Health} Organization), di Indonesia kanker serviks menempati urutan kedua setelah kanker payudara. Didapatkan kasus baru kanker serviks sekitar 20.928 dan kematian akibat kanker serviks dengan persentase 10,3\% insiden kanker serviks sebanyak 100 per 100.000 penduduk pertahun dan angka ini diperkirakan akan terus meningkat 25\% dalam kurun waktu 10 tahun mendatang jika tidak dilakukan tindakan pencegahan ${ }^{2}$
Data Badan Pusat Statistik (BPS) pada tahun 2010 menunjukkan jumlah wanita Indonesia yang berusia 30-50 tahun sejumlah 35.950 .765 orang. Sampai dengan tahun 2012 dari 575.503 orang telah melakukan skrining inspeksi visual asam asetat (IVA), terdapat 25.805 orang dengan hasil IVA positif ${ }^{3}$

Hasil studi pendahuluan di RW 03 Kelurahan Patih Galung dengan melakukan wawancara kepada ketua Posyandu Melati, bahwa di kelurahan Patih Galung untuk target pemeriksaan IVA ini sekitar 225 orang pada tahun 2019 di hitung dari setiap RT. Dan target setiap RT ini sekitar 50 orang. Berdasarkan informasi yang di peroleh bahwa ibu-ibu di Kelurahan ini rata-rata sudah mengetahui tentang kanker serviks tetapi belum semuanya melakukan pemeriksaan IVA. Hal ini dikarenakan beberapa faktor seperti mereka malu untuk melakukan pemeriksaan ini dan juga ketidaksiapan dalam menerima kenyataan hasil pemeriksaan. Mereka takut bahwa hasil yang di tunjukkan adalah positif kanker serviks

\section{METODE PENELITIAN}

Sampel penelitian adalah sebagian yang diambil dari keseluruhan objek yang diteliti dan dianggap mewakili seluruh populasi ${ }^{4}$

Pengambilan sampel pada penelitian ini menggunakan metode Accidental sampling, yaitu pengambilan sampel dilakukan dengan mengambil kasus atau responden yang kebetulan ada atau tersedia disuatu tempat ${ }^{4}$

Sampel penelitian ini adalah ibu-ibu yang sudah menikah yang datang berkunjung ke pemeriksaan IVA ini. 
p-ISSN: 2503-1392

e-ISSN: 2620-5424

\section{HASIL}

Tabel 1. Hubungan Antara Usia Ibu Dengan Kunjungan Pemeriksaan IVA

\begin{tabular}{cccccccc}
\hline \multirow{2}{*}{ Usia ibu } & \multicolumn{6}{c}{ Kunjungan pemeriksaan IVA } & \\
\cline { 2 - 6 } & \multicolumn{3}{c}{ Ya } & \multicolumn{3}{c}{ Tidak } & \multicolumn{2}{c}{ Jumlah } & Pvalue \\
\cline { 2 - 6 } & $\mathbf{N}$ & $\mathbf{\%}$ & $\mathbf{n}$ & $\mathbf{\%}$ & $\mathbf{N}$ & $\boldsymbol{\%}$ & \\
\hline Resiko rendah & 29 & 64,4 & 6 & 13,3 & 35 & 77,8 & \\
Resiko tinggi & 3 & 6,7 & 7 & 15,6 & 10 & 22,2 & 0,003 \\
\hline Jumlah & $\mathbf{3 2}$ & $\mathbf{7 1 , 1}$ & $\mathbf{1 3}$ & $\mathbf{2 8 , 9}$ & $\mathbf{4 5}$ & $\mathbf{1 0 0}$ & \\
\hline
\end{tabular}

Berdasarkan hasil analisa bivariat Uji statistik menggunakan Chi-Square didapatkan $p$-value $=$ 0,003 yang berarti ada hubungan yang bermakna antara usia ibu dengan kunjungan pemeriksaan IVA.

Hasil penelitian ini sejalan dengan penelitian Pertiwi, dkk (2015) tentang faktor-faktor yang berhubungan dengan kunjungan pemeriksaan IVA di Dusun Tajem Depok Sleman Berdasarkan uji statistic menggunakan uji ChiSquare yang diperoleh nilai $p$-value $>0,05$ diperoleh nilai signifikansi sebesar nilai $\rho=0,003$ yang berarti ada hubungan yang bermakna antara usia ibu dengan kunjungan pemeriksaan IVA.

Tabel 2. Hubungan Pengetahuan Dengan Kunjungan Pemeriksaan IVA

\begin{tabular}{|c|c|c|c|c|c|c|c|}
\hline \multirow{3}{*}{ Pengetahuan } & \multicolumn{6}{|c|}{ Kunjungan pemeriksaan IVA } & \multirow{3}{*}{ Pvalue } \\
\hline & \multicolumn{2}{|c|}{ Ya } & \multicolumn{2}{|c|}{ Tidak } & \multicolumn{2}{|c|}{ Jumlah } & \\
\hline & $\mathbf{N}$ & $\%$ & $\mathbf{n}$ & $\%$ & $\mathbf{N}$ & $\%$ & \\
\hline Baik & 30 & 66,7 & 6 & 13,3 & 36 & 80 & \\
\hline Kurang & 2 & 4,4 & 7 & 15,6 & 9 & 20 & 0,001 \\
\hline Jumlah & 32 & 71,1 & 13 & 28,9 & 45 & 100 & \\
\hline
\end{tabular}

Berdasarkan hasil analisa bivariat Uji statistik menggunakan Chi-Square didapatkan $p$-value $=0,001$ yang berarti ada hubungan yang bermakna antara pengetahuan dengan kunjung pemeriksaan IVA Hasil penelitian ini sesuai dengan penelitian Pertiwi, dkk (2015) tentang faktor-faktor yang berhubungan dengan kunjungan pemeriksaan IVA di Dusun Tajem Depok Sleman Berdasarkan uji statistic menggunakan uji Chi-Square yang diperoleh nilai $p$-value $>0,05$ yang berarti ada hubungan yang bermakna antara pengetahuan ibu dengan kunjungan pemeriksaan IVA. 
p-ISSN: 2503-1392

e-ISSN: 2620-5424

Tabel 3. Hubungan Pendidikan Ibu dengan Kunjungan Pemeriksaan IVA

\begin{tabular}{cccccccc}
\hline \multirow{2}{*}{$\begin{array}{c}\text { Pendidikan } \\
\text { ibu }\end{array}$} & \multicolumn{4}{c}{ Kunjungan pemeriksaan IVA } & \multirow{2}{*}{ Ya } & \multicolumn{3}{c}{ Tidak } & \multicolumn{3}{c}{ Jumlah } & Pvalue \\
\cline { 2 - 7 } & $\mathbf{N}$ & $\mathbf{\%}$ & $\mathbf{n}$ & $\mathbf{\%}$ & $\mathbf{N}$ & $\mathbf{\%}$ & \\
\hline Tinggi & 30 & 66,7 & 3 & 6,7 & 33 & 73,3 & \\
Rendah & 2 & 4,4 & 10 & 22,2 & 12 & 26,7 & 0,000 \\
\hline Jumlah & $\mathbf{3 2}$ & $\mathbf{7 1 , 1}$ & $\mathbf{1 3}$ & $\mathbf{2 8 , 9}$ & $\mathbf{4 5}$ & $\mathbf{1 0 0}$ & \\
\hline
\end{tabular}

Berdasarkan hasil analisa bivariat Uji statistik menggunakan Chi-Square didapatkan $p$-value $=0,000$ yang berarti ada hubungan yang bermakna antara pendidikan ibu dengan kunjungan pemeriksaan IVA.

Hasil penelitian ini sejalan dengan penelitian Handayani, (2017) tentang faktor-faktor yang mempengaruhi perilaku pemeriksaan IVA pada Wanita Usia Subur di Desa Penyak Kecamatan Koba Kabupaten Bangka Tengah Berdasarkan uji statistic menggunakan uji Chi-Square yang diperoleh nilai pendidikan responden $p$ value 0,003 .

\section{KESIMPULAN}

Dari hasil penelitian yang dilakukan di kelurahan patih galung, peneliti menarik beberapa kesimpulan :

1. Ada hubungan antara usia ibu dengan Kunjungan Pemeriksaan IVA di Kelurahan patih galung Kota Prabumulih tahun 2019 dengan Chi square didapatkan $p$ value $=0,003$ lebih kecil dari $\alpha(0,05)$

2. Ada hubungan antara pengetahuan dengan Kunjungan Pemeriksaan IVA di Kelurahan patih galung Kota Prabumulih tahun 2019 dengan Chi-Square didapatkan $p$-value $=0,001$ lebih kecil dari $\alpha(0,05)$.

3. Ada hubungan antara pendidikan ibu dengan Kunjungan Pemeriksaan IVA di Kelurahan patih galung Kota Prabumulih tahun 2019 dengan Chi square didapatkan $p$ value $=0,000$ lebih kecil dari $\alpha(0,05)$.

\section{SARAN}

Disarankan kepada tenaga kesehatan di Poliklinik KIA dan PONED puskesmas untuk dapat meningkatkan kualitas pelayanan kebidanan sehingga ibu dapat mengetahui manfaat dari pemeriksaan IVA meningkatkan penyuluhan tentang pentingnya pemeriksaan IVA.

\section{DAFTAR PUSTAKA}

1. Rasjidi. (2009). Masalah Kesehatan Perempuan di Negara Berkembang. Jakarta: Sagung Seto.

2. Dewi. (2017). Hubungan Pengetahuan Dan Sikap Ibu Terhadap Deteksi Dini Kanker Serviks Dengan Pemeriksaan IVA Di Puskesmas Sekupang Tahun 2017.

3. Depkes. (2012). Data BPS, Jumlah Wanita yang Melakukan Skrinning IVA. Retrieved Februari 20, 2020, from http://bps.go.id

4. Notoatmodjo. (2014). Metodologi Penelitian Kesehatan. Jakarta: Rineka Cipta.

5. Nuur Desi Eka Pertiwi, I. (2015). FaktorFaktor Yang Berhubungan Dengan Kunjungan Pemeriksaan IVA/PAP SMEAR Pada Ibu-Ibu PKK Di Dusun Tajem Depok Sleman.

6. Handayani. (2017). Faktor-Faktor Yang Mempengaruhi Perilaku Pemeriksaan IVA Pada Wanita Usia Subur Di Desa Penyak Kecamatan Koba Kaabupaten Bangka Tengah Tahun 2017.. 